\title{
Mikko Hallman - A Major Translator of Basic Science into Neonatal Medicine
}

\author{
Christian P. Speer $^{a}$ Henry L. Halliday ${ }^{b}$ \\ a University Children's Hospital, University of Würzburg, Würzburg, Germany; ${ }^{b}$ Retired Professor of Child Health, \\ Queen's University of Belfast, Belfast, UK
}

Mikko Hallman was born in 1945 in Helsinki where he grew up in a family of five children. His father Niilo, who died in January 2011, was the very well-respected Chairman and Chief of Pediatrics at Helsinki University from 1957 to 1983 [1]. Mikko spent a lot of his childhood within or immersed in the work of the Children's Hospital.

In 1970, he graduated in medicine at Helsinki University and continued his studies in the Department of Medical Chemistry, University of Helsinki. In 1972, he defended his doctoral thesis on 'Perinatal development of mitochondrial oxidative enzymes' and decided to specialize in pediatrics. During early residency, he studied lung surfactant and obtained the Fogarty fellowship for neonatal studies with Louis Gluck in San Diego from 1973 to 1975. After this, Mikko completed his education in pediatrics and neonatology in Helsinki, and returned to San Diego from 1979 to 1983 as an Assistant/Associate Professor of Pediatrics. Previous experience in basic research allowed him to define the minor surfactant phospholipids for the first time in the mid-1970s. He expanded these studies to ontogeny, surface activity, turnover and recycling of surfactant phospholipids, and determined the relationship of the new surfactant indices to risk of respiratory distress syndrome (RDS) $[2,3]$ and later to ARDS. Mikko discovered that myoinositol alters the metabolism of acidic surfactant phospholipids and how it influences differentiation [4].

\section{KARGER}

Fax +4161306 1234 E-Mail karger@karger.ch www.karger.com

\section{(c) 2011 S. Karger AG, Basel}

$1661-7800 / 11 / 1003-0300 \$ 38.00 / 0$

Accessible online at:

www.karger.com/neo

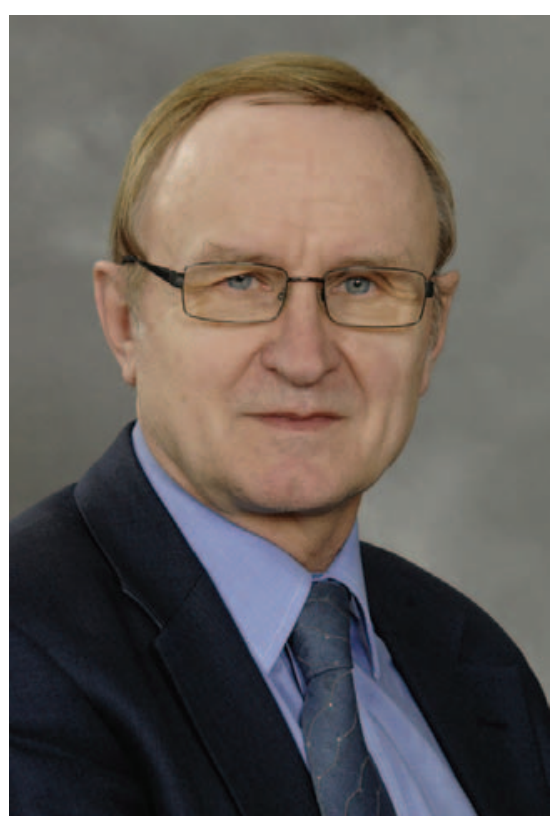

By the late 1970s, studies on lung maturity and prediction of RDS led him to propose that the large surfactant pool in amniotic fluid from term pregnancies could be harvested, tested and given to preterm infants at risk of RDS [5]. This concept had already been discarded by John Clements and colleagues, who used nebulized saturated

Prof. Christian P. Speer, MD, FRCPE

University Children's Hospital, University of Würzburg Josef-Schneider-Strasse 2

DE-97080 Würzburg (Germany)

Tel. +49931 201 27831, E-Mail speer_c@ kinderklinik.uni-wuerzburg.de 
lecithin without clinical effect in 1964 [6]. In 1972, however, Göran Enhörning and Bengt Robertson [7] demonstrated (and were the first to do so) that natural surfactant could effectively improve oxygenation and lung function in preterm rabbits.

Since the potential long-term harmful effects of giving heterologous surfactant to preterm infants were unknown at this time, it was necessary to conduct a trial using homologous surfactant to study the immunology. Isolation and testing of surfactant from term amniotic fluid was introduced by Mikko in San Diego and later replicated in Helsinki. Together with Allen Merritt and colleagues, he planned and executed series of randomized bicenter trials on human surfactant substitution to small preterm infants [5]. Together they first reported the results of the randomized trials in 1985 and 1986, showing that surfactant treatment in preterm infants with or at risk of RDS increased survival without bronchopulmonary dysplasia (BPD) $[8,9]$. A further trial compared prophylactic and rescue surfactant [10]. In 1988, Mikko and his colleagues reported that peptide fragments of SP-B dramatically improved surface activity of phospholipids and this mixture was effective in a model of RDS [11]. By the time Revak et al. [12] introduced their peptide-containing surfactant in 1991, the first heterologous surfactants were commercially available [13]. In 1994, the Hallman team [14] reported that the beneficial effects of antenatal steroid and postnatal surfactant were additive, but despite this antenatal steroids were rarely used in the numerous trials reporting the efficacy of surfactant therapy.

After 7 years as a specialist in neonatal medicine, Chief of the Division of Neonatology in Department of Obstetrics, Helsinki University Central Hospital, and intermittently as a senior investigator of the Finnish Academy, Mikko decided to return to California, this time as a Professor of Pediatrics at the Universtiy of California, Irvine from 1989 to 1997. His research centered on the role of antenatal inflammation in premature birth. In 1993, he and Kristina Bry reported that the combination of maternal TNF- $\alpha$ and IL-1 caused preterm birth in experimental animals and that this was prevented by the anti-inflammatory cytokine TGF- $\beta 2$ [15]. The old observation by Gluck and coworkers that chorioamnionitis is associated with accelerated lung maturity led to another experiment demonstrating that administration of IL-1 to the amniotic sac of an immature fetus induced a striking maturation of the surfactant system $[16,17]$. Besides the molecular link between spontaneous preterm birth and lowered risk of RDS, another remarkable connection be- tween early inflammatory exposure and risk of BPD was observed by several investigators.

In 1997, Mikko faced new challenges when he returned to Finland as Chairman of Pediatrics at Oulu University Hospital and Oulu University. A homogenous population of children, regionalized effective health care and new laboratory technologies allowed Mikko to establish a reputable research team with talented investigators, such as Mika Rämet. His current research is aimed at defining the genetic background and individual genes, influencing susceptibility to respiratory disease of preterm infants. They have reported certain new candidate genes for RDS and BPD and the first genomic study on susceptibility to spontaneous preterm birth [18, 19]. In addition, Mikko's team has planned and participated in many multicenter trials involving antenatal repeat doses of steroids, as well as neonatal steroids and nitric oxide. These and other ongoing trials aim to enhance fetal lung maturity [20], improve survival and prevent BPD.

Mikko Hallman has received many awards related to his research, including the most prestigious award for medical research in Finland - the Matti Äyräpää Prize in 1987, the Arvo Ylppö Medal in 1992, the Chiesi Prize for Excellence in Neonatology in 2004 and the Arvo Ylppö Pot in 2005. He was nominated to the Finnish Academy of Science in 2002 and has served as a board member and international reviewer for many organizations, foundations and scientific journals, including the role of associate editor of Acta Paediatrica.

Mikko has published about 400 original articles, reviews and book chapters and he continues to be active as the leader of his research group in Oulu University. He has been a research mentor to numerous neonatal fellows and has supervised many doctoral dissertations in Finland. Having been involved in the early days of surfactant research, Mikko Hallman remains interested in this versatile defense system that as an immune modulator has functions well beyond reduction of surface tension. Moreover, he emphasizes the importance of an international network of academic centers with strong neonatal research programs, multidisciplinary collaboration, and active projects in basic and clinical neonatology. Mikko Hallman is an extraordinarily modest, gentle and warm personality with a brilliant and very creative mind, and has made vast contributions to our current understanding of RDS and BPD. He is one of the most prominent researchers in perinatal and neonatal medicine, successfully translating the results of his basic research into clinical practice. 


\section{References}

1 Obituary: Niilo Hallman. Lancet 2011;377: 634.

-2 Hallman M, Kulovich M, Kirkpatrick E, Sugarman RG, Gluck L: Phosphatidylinositol and phosphatidylglycerol in amniotic fluid: indices of lung maturity. Am J Obst Gynecol 1976;125:613-617.

3 Hallman M, Teramo K: Measurement of the lecithin/sphingomyelin ratio and phosphatidylglycerol in amniotic fluid: an accurate method for the assessment of fetal lung maturity. Br J Obst Gynaecol 1981;88:806-813.

$\checkmark 4$ Hallman M, Saugstad OD, Porreco RP, Epstein BL, Gluck L: Role of myoinositol in regulation of surfactant phospholipids in the newborn. Early Hum Devel 1985;10:245254.

$\checkmark 5$ Hallman M, Merritt TA, Schneider H, Epstein BL, Mannino F, Edwards DK, Gluck L: Isolation of human surfactant from amniotic fluid and a pilot study of its efficacy in respiratory distress syndrome. Pediatrics 1983; 71:473-482.

6 Chu J, Clements JA, Cotton E, Klaus MH, Sweet AY, Thomas MA, Tooley WH: Preliminary report: the pulmonary hypoperfusion syndrome. Pediatrics 1965;35:733-742.

7 Enhörning G, Robertson B: Lung expansion in the premature rabbit fetus after tracheal deposition of surfactant. Pediatrics 1972;50: 58-66.
Hallman M, Merritt TA, Jarvenpaa AL, Boynton B, Mannino F, Gluck L, Moore J, Edwards D: Exogenous human surfactant for treatment of severe respiratory distress syndrome: a randomized prospective trial. J Pediatr 1985;106:963-969.

$\checkmark 9$ Merritt TA, Hallman M, Bloom BT, et al: Prophylactic treatment of very premature infants with human surfactant. N Engl J Med 1986;315:785-790.

10 Merritt TA, Hallman M, Berry C, et al: Randomized, placebo-controlled trial of human surfactant given at birth versus rescue administration in very low birth weight infants with lung immaturity. J Pediatr 1991;118: 581-594.

$>11$ Revak SD, Merritt TA, Degryse E, Stefani L, Courtney M, Hallman M, Cochrane CG: Use of human surfactant low molecular weight apoproteins in the reconstitution of surfactant biologic activity. J Clin Invest 1988;81: 826-833.

-12 Revak SD, Merritt TA, Hallman M, Heldt G, La Polla RJ, Hoey K, Houghten RA, Cochrane CG: The use of synthetic peptides in the formation of biophysically and biologically active pulmonary surfactants. Pediatr Res 1991;29:460-465.

13 Jobe AH: Pulmonary surfactant therapy. N Engl J Med 1993;328:861-868.
14 Kari MA, Hallman M, Eronen M, Teramo K, Virtanen M, Koivisto M, Ikonen RS: Prenatal dexamethasone treatment in conjunction with rescue therapy of human surfactant: a randomized placebo-controlled multicenter study. Pediatrics 1994;93:730-736.

15 Bry K, Hallman M: Transforming growth factor-beta 2 prevents preterm delivery induced by interleukin-1 alpha and tumor necrosis factor-alpha in the rabbit. Am J Obst Gynecol 1993;168:1318-1322.

16 Bry K, Lappalainen U, Hallman M: Intraamniotic interleukin-1 accelerates surfactant protein synthesis in fetal rabbits and improves lung stability after premature birth. J Clin Invest 1997;99:2992-2999.

17 Emerson GA, Bry K, Hallman M, Jobe AH, Wada N, Ervin MG, Ikegami M: Intra-amniotic interleukin-1 alpha treatment alters postnatal adaptation in premature lambs. Biol Neonate 1997;72:370-379.

-18 Karjalainen MK, Haataja R, Hallman M: Haplotype analysis of ABCA3: association with respiratory distress in very premature infants. Ann Med 2008;40:56-65.

19 Hallman M, Haataja R: Surfactant protein polymorphisms and neonatal lung disease. Semin Perinatol 2006;30:350-361.

20 Hallman M, Peltoniemi O, Kari MA: Enhancing functional maturity before preterm birth. Neonatology 2010;97:373-378. 